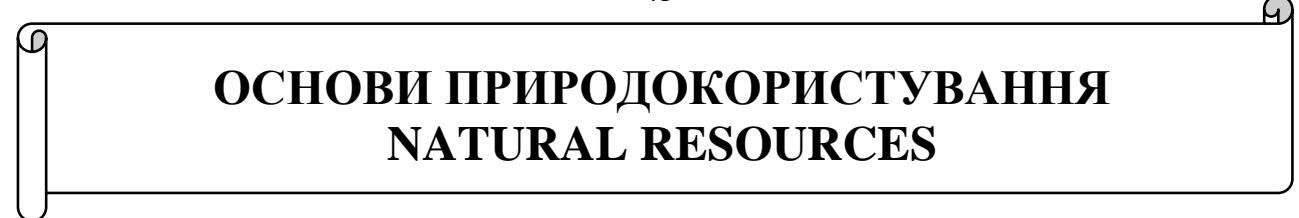

UDC 504.064.2

Tetiana I. Kryvomaz, Dr, Professor of Departament of Labour and Environment Protection ORCID ID: 0000-0002-4161-9702 e-mail: ecol@i.ua

Dmytro V. Varavin, Postgraduate student

ORCID ID: 0000-0002-4161-9702 e-mail: d.varavin@icloud.com

Kyiv National University of Construction and Architecture, Kyiv, Ukraine

\title{
WAYS TO IMPROVE THE ENVIRONMENTAL SAFETY OF THE URBANIZED ENVIRONMENT IN CONNECTION WITH THE COVID-19
}

\begin{abstract}
Pandemics of the past have caused all major urban transformations and have affected architecture, design, and infrastructure. The built environment is formed under the influence of diseases and precautions designed to ensure the population's health, hygiene, and comfort. Construction trends have always reflected the ability to evolve after the crisis, and in the context of the COVID-19 pandemic, the most vulnerable to the risk of infection was densely populated cities. Creating an environmentally safe environment to withstand epidemics and other possible emergencies requires a radical overhaul of planning theories and new urban space models. It is necessary to increase the spatial functionality and decentralization of megacities by increasing the potential of micromobility and new transport strategies. Emergency modeling with the help of digital technologies allows for creating an operational system of response and forecasting various scenarios of development of ecologically dangerous situations. High-quality criteria for the built environment parameters, which are used in green construction, aimed at preserving human health, are becoming relevant. Strategies include increasing natural light, improving ventilation, eliminating hazards from the air and surfaces, using natural materials, and landscaping. Modern technologies provide various automatic cleaning strategies with the use of built-in devices for sanitary spraying, disinfecting lighting, and temperature treatment of premises, contactless building management technologies.
\end{abstract}

Key words: environmental safety; urban environment; COVID-19; green building

(C) Т.І. Кривомаз, Д.В. Варавін, 2020 


\title{
Т.І. Кривомаз, Д.В. Варавін
}

Київський національний університет будівництва та архітектури, м. Київ, Україна

\section{ШЛЯХИ ПІДВИЩЕННЯ ЕКОБЕЗПЕКИ УРБАНІЗОВАНОГО СЕРЕДОВИЩА У ЗВ'ЯЗКУ 3 ПАНДЕМІЕЮ COVID-19}

\begin{abstract}
Анотація. Пандемї минулого стали приводом для всіх значних трансформацій міст і впливали на архітектуру, дизайн та інфраструктуру. Побудоване середовище сформовано під впливом хвороб та запобіжних заходів, розроблених для забезпечення здоров'я, гігієни та комфорту населення. Тендениії будівниитва завжди відображали здатність еволючіонувати після кризи, а в умовах пандемії COVID-19 найбільш вразливими до ризику зараження виявились густонаселені мегаполіси. Створення екобезпечного середовища для протистояти епідеміям та іншим можливим надзвичайним ситуаціям потребує докорінного перегляду теорій планування та розробки нових моделей міського простору. Необхідно підвищувати просторову функиіональність та децентралізацію мегаполісів із збільшенням потениіалу мікромобільності та новими транспортними стратегіями. Моделювання надзвичайних ситуацій за допомогою ичиррових технологій дозволяє створити оперативну систему реагування $i$ прогнозування різних сценарїв розвитку екологічно небезпечних ситуачій. Актуальними стають високі критерї якості параметрів побудованого середовища, які застосовуються у зеленому будівництві та спрямовані на збереження здоров'я людей на всіх етапах життєвого ииклу будівель. Суттєвими факторами є збільшення природного освітлення, поліпшення вентиляиії, усунення небезпечних чинників з повітря та поверхонь, використання природних матеріалів, оздоровче озеленення приміщень. Сучасні технології передбачають різноманітні стратегії автоматичного очищення з використанням вбудованих в інтер'єри приладів для санітарного обприскування, дезінфікуючого освітлення та температурної обробки приміщень, а також безконтактні технології управління будівлями.
\end{abstract}

Ключові слова: екологічна безпека; урбанізоване середовище; COVID-19; зелене будівниитво

\section{Вступ}

Сьогодні вже очевидно, що внаслідок пандемії COVID-19 світ змінився назавжди і всі подальші плани мають бути узгоджені з особливими вимогами та заходами щодо запобігання поширенню захворювання. Пандемія вплинула на всі сфери людського життя, що потребує докорінних змін у способах взаємодії та середовища існування людей. Особливо це стосується урбанізованих територій з великою концентрацією населення, що збільшує небезпеку зараження та ризики поширення вірусу. Ця глобальна пандемія суттєво вплинула на наше особисте та професійне життя i має пряме відношення до самих основ міського планування та теорії та практики архітектури $[7,22]$. Нинішня криза охорони здоров'я обумовлює необхідність розвитку побудованого середовища для підвищення рівня безпеки, що допомагає запобігти поширенню інфекцій. Це стосується планування, забудови та облаштування урбанізованих територій, а також способів взаємодії людей та нових шляхів функціонування людини у побудованому 
середовищі. I саме зелене будівництво $є$ ефективним інструментом для трансформації урбанізованого середовища у відповідності до екобезпеки нового способу існування людей в умовах пандемії і у постпандемічний період. Слід відзначити, що критерії та аспекти зеленого будівництва можуть послужити основою для нових стандартів екобезпеки взаємодії людей в урбанізованому середовищі. Адже в концепції зеленого будівництва передбачено не тільки мінімізацію впливу будівельної галузі на навколишнє середовище, але й акцентовано увагу на збереженні здоров'я та покращенні комфорту і якості життя людей у побудованому середовищі. Вже зараз очевидно, що світ змінився назавжди і ніколи не стане таким, як до пандемії. Замість того, щоб бідкатись та впадати у розпач від невтішних прогнозів, треба зосередитись на пошуку шляхів вирішення проблеми. Найбільш актуальні зараз мультидисциплінарні дослідження спрямовані на заохочення до пошуку нових ідей, формування сучасних тенденцій та теорій планування урбанізованих територій, щоб забезпечити необхідний захист від інфекційних захворювань [22]. Професіонали в галузі архітектури та містобудування, дизайну побудованих середовищ та екобезпеки вже переключили свою увагу на пошук нових ідей для захисту населення у постпандемічну еру $[7,13,17,22]$.

\section{Постановка завдання}

Мета даного дослідження: аналіз ефективних рішень та пошук шляхів підвищення рівня екобезпеки урбанізованого середовища у зв'язку 3 пандемією COVID-19. В узгодженні з метою визначено наступні завдання:

- узагальнити досвід минулих пандемій в аспекті змін, які відбулися у побудованому середовищі внаслідок адаптації до нових гігієнічних вимог;

- проаналізувати особливості взаємодії людей 3 урбанізованим середовищем в умовах пандемії COVID-19;

- визначити напрямки тенденцій та заходів, які необхідно впровадити для підвищення рівня екобезпеки міських просторів і інфраструктури, а також нових технологій планування будівель у постпандемічний період.

\section{Результати досліджень}

Насамперед слід зазначити, що у XXI ст. людство вже потерпало від багатьох епідемій. Найбільш відомими вважають епідемію важкого гострого респіраторного синдрому SARS у 2002-2004 рр. (викликана коронавірусом SARS-CoV), епідемію свинячого грипу у 2009-2010 pp. (вірус грипу A/H1N1), епідемію близькосхідного респіраторного синдрому MERS у 2012 p. (коронавірус MERS-CoV), а також епідемію хвороби, спричиненої вірусом Ебола у 2014-2015 pp. [1, 2, 4]. Спалах COVID-19 вперше було зафіксовано в грудні 2019 р. і вже 30 січня ВООЗ оголосила надзвичайну ситуацію міжнародного масштабу в галузі охорони здоров'я, а 11 березня 2020 р. епідемію було офіційно визнано пандемією [28]. В результаті порівняння генетичних даних SARS-CoV-2 з геномами інших коронавірусів доведено, що новий вірус з'явився в результаті природного відбору і «не є лабораторною конструкцією чи цілеспрямовано керованим вірусом» [8].

Вірусологи вже давно попереджали, що світу слід готуватись до глобальних пандемій і протягом всієї історії віруси і бактерії були безжальними 
селекціонерами людства [4]. Водночас пандемії минулого стали приводом для всіх значних трансформацій міст і впливали на архітектуру, дизайн та інфраструктуру. Починаючи з інтер'єрів і закінчуючи міським плануванням, наше побудоване середовище сформовано під впливом хвороб, які атакували людство протягом всієї історії його існування. Багато тенденцій в архітектурі та урбанізмі, які ми бачимо сьогодні, походять від запобіжних заходів, вжитих для забезпечення здоров'я, гігієни та комфорту міських жителів.

3 моменту, коли люди перейшли від кочового життя до осілого, виникла проблема утилізації відходів та підтримання чистоти. Для мінімізації ризиків поширення інфекційних захворювань, люди переробили дизайн інтер'єру, архітектуру та інфраструктуру поселень. 3 розвитком та розростанням поселень актуальності набули проблеми водопостачання та каналізації. У XIV ст. внаслідок бубонної чуми відбулася фундаментальна перебудова міст, з'явились великі площі та відкриті громадські простори, відокремились карантинні зони. Без спалаху холери не було б реконструкції центру Лондона і санітарних інновацій. В епоху промисловості холера та тиф спонукали уряд до санітарної реформи. Ці епідемії сприяли розробці систем водопостачання та водовідведення, а проведення підземного трубопроводу обумовило розширення та вирівнювання вулиць, що кардинально змінило вигляд міста. Третя пандемія чуми в 1855 р. змінила дизайн всього: від водостічних труб до порогів дверей та фундаментів будівель $[22,12]$.

У XX ст. інфекційні захворювання відігравали роль рушійних факторів оновлення міст. Архітектори-модерністи розглядали дизайн як ліки від хвороби перенаселених міст, де періодичні спалахи туберкульозу, черевного тифу, поліомієліту та іспанського грипу підштовхували до очищення міських нетрів, житлових реформ та нових методів управління відходами $[15,18,23]$. Естетику модерну пов'язують із запобіжними заходами від інфекційних хвороб XX ст., зокрема туберкульозу. Модернізм характеризується стерильністю, сталлю, склом, великими світлими просторами [21]. Окрім естетичної привабливості, ці риси втілювали модерністські ідеї щодо цілющих ефектів світла, повітря та природи. Архітектори модернізму розробляли будівлі 3 великими вікнами, балконами, 3 покращеною вентиляцією та відокремленням індустріальних та житлових функціональних зон. Світлі поверхні з сучасними матеріалами створювали враження стерильності та чистоти, підкреслюючи лікувальні властивості середовища [14]. Архітектурні конструкції відображали стиль епохи чистоти форм з відмовою від орнаментів на потребу санітарно-гігієнічним вимогам. Таким чином, тенденції будівництва завжди відображали здатність еволюціонувати після кризи [19, 23$]$.

В умовах нинішньої кризи охорони здоров'я найбільш вразливими до ризику зараження виявились мегаполіси. Густонаселені міста перетворились у джерела розповсюдження інфекції, а передмістя та приватний сектор виявились найбільш безпечними місцями в період пандемії [28]. Можливість працювати дистанційно і доставка всього необхідного до місця проживання у комбінації з свіжим повітрям та природою стали вагомими стимулами для багатьох людей перебратися у передмістя або навіть у сільську місцевість не тільки на періоди карантину. Можливо, внаслідок пандемії вдасться знизити темпи урбанізації, особливо завдяки розвитку сучасних цифрових технологій, що надають можливість для дистанційної праці та навчання. Під час пандемії близькість людей до густонаселених міст створює додаткові ризики і виявлено 
кореляцію між щільністю населення та підвищенням рівня захворюваності COVID-19 [22]. Пандемія ще раз підтвердила доцільність децентралізації мегаполісів, і концепція «центр поруч», прописана в стратегії розвитку міста Києва, стає надзвичайно актуальною у кризових умовах [20]. Все необхідне для комфортного життя повинне знаходитись на відстані пішої доступності від місця проживання: лікарні, торгівельні центри, школи, дитячі садки та інші заклади першої необхідності. Дотримання соціальної дистанції потребує докорінного перегляду теорій планування у всіх типах будівель, створення нових моделей та конфігурацій міського простору $[22,26]$. Нові підходи у плануванні передбачають розширення міст по горизонталі з більш доступними відкритими просторами, що важливо для запобігання розповсюдженню інфекцій та хвороб [23, 24].

Перебудова вуличного простору потрібна для того, щоб зробити міські райони більш стійкими до реагування на надзвичайні ситуації, протистояти епідеміям та іншим можливим надзвичайним ситуаціям будь-якого роду в майбутньому. Соціальна дистанція $є$ першочерговим способом стримування розповсюдження вірусу, тому формат громадських просторів потребує відповідних змін. У місцях традиційного скупчення людей необхідно підвищувати просторову функціональність та чітко планувати потоки переміщення населення міст. Системи імітаційного моделювання розраховують рух потоків людей в різних сценаріях і пропонують раціональні рішення для підвищення рівня безпеки. Коронавірус спонукав владу обмежити доступ до більшості громадських приміщень та великих торгових площ. Зі зростанням популярності он-лайн торгівлі та служби доставок в умовах ізоляції великі торгівельні центри поступово втрачають свою актуальність. Ресторани і кафе в нових умовах повинні збільшити відстань між столиками та розширити проходи для відвідувачів і персоналу. Ця пандемія може принципово змінити спосіб діяльності громадських закладів у майбутньому [19].

Модифікація зон відпочинку та зелених міських насаджень полягає у переході взаємодії людей з природою у містах на новий рівень із створенням продуманого плану координації щільності потоків людей. Мешканцям міст потрібна фізична взаємодія з живими рослинами для покращення фізичного та психічного здоров'я населення. Зелені зони розглядають у якості інструментів перезавантаження і соціалізації, які забезпечують можливість відновлення після стресу ізоляції, де люди можуть бачити один одного на безпечній відстані. Новим трендом стане децентралізована мережа зелених насаджень i лаконічне облаштування великих природних територій, яке дозволить людям комфортно проводити час на природі, зберігаючи безпечну дистанцію [17]. Вертикальні міські сади, тераси та впровадження систем зелених дахів допоможе вирішити більшість проблем самоізоляції і водночас забезпечить стійкий розвиток міст в узгодженні з принципами зеленого будівництва $[8,27]$. Для зменшення ризиків під час самоізоляції доцільно ініціювати розвиток міського сільського господарства [22]. Зелені дахи позиціонують як п'ятий фасад будівель для місць відпочинку та вирощування окремих елементів харчового раціону. Однак під час проектування зелених дахів, призначених для виробництва харчових продуктів, можуть знадобитися додаткові розрахунки для дотримання особливих вимог екобезпеки [5]. Актуальними стають інтегровані підходи з використанням новітніх проектів та технологій 3 архітектурними підходами зеленого будівництва [15]. 
Транспортні стратегї. Під час карантину значно скоротились транспортні переміщення, що призвело до значних скорочень викидів та позитивно вплинуло на стан навколишнього середовища у багатьох мегаполісах [10]. В епоху постпандемії необхідні альтернативні транспортні рішення із збільшенням потенціалу мікромобільності та розвитком мультимодального транспорту. Першочергова перевага надається пішоходам та велотранспорту, як найбільш сприятливим для здоров'я та довкілля способам пересування у місті. Нові транспортні плани передбачають розширення мережі велосипедних та пішохідних доріжок з безпечними маршрутами в усіх міських зонах. Париж і Мілан вже оприлюднили свої плани по створенню сотень кілометрів нових велосмуг для забезпечення соціальної дистанції та сприяння підтриманню здоров'я людей [11]. У стратегії розвитку Києва також передбачено розвиток велотранспорту та облаштування нових пішохідних зон у столиці, і дійсно, останніми роками спостерігаються значні зрушення у цьому напрямку [20]. Слід зазначити, що всі ці заходи, як і надання переваги громадському i альтернативним видам транспорту, є основою транспортного планування інфраструктури у зеленому будівництві. Проте громадський транспорт в умовах пандемії потребує суттєвих трансформацій із відмежуванням безпечного простору для кожного пасажира, захисних екранів, вентиляції та регулярної санації сучасними способами.

Соціальні комунікації. Фізична ізоляція є загальноприйнятою універсальною стратегією, проте цей запобіжний захід призвів до цілої низки соціальних та психофізичних наслідків у суспільстві [18]. Необхідність дистанційних комунікацій та цифрова трансформація під час карантину змінила форми соціальних взаємодій, і у деяких сферах ці зміни набувають довгострокового характеру. Нова гібридна форма комунікацій офф-лайн та он-лайн впливає на функціонування міст, формат житла, медицину, цифрові сервіси і навіть на відносини між людьми. Вплив обмежувальних заходів на повсякденне життя має довгострокові наслідки, що призводять до глибинних трансформацій соціальних взаємодій. COVID-криза значно підвищила рівень тривожності людей та суттєво знизила ступінь довіри населення до мас-медіа [1].

Завдяки пандемії процес діджиталізації урбаністичних просторів пришвидшує оберти. Все більше сфер життя переходить в он-лайн - робота, освіта, спорт, магазини, розваги та культурні зв'язки. Таким чином, зменшується потреба у традиційних фізичних просторах, на зміну яким приходять віртуальні платформи [18]. Цифровий світ значною мірою визначає стиль, спосіб життя, уподобання, інтереси, сприйняття реальності у всіх сенсах. Хоча нові технології створюють додаткові труднощі, водночас вони відкривають нові можливості застосовування інноваційних рішень для розвитку SMART-city i віртуальних програм в урбаністичному середовищі. Зростає запит на моделювання надзвичайних ситуацій за допомогою цифрових технологій, що дозволяють створити оперативну систему реагування i прогнозування наслідків різних сценаріїв розвитку екологічно небезпечних ситуацій. Глобальна пандемія занурила людей у абсолютно новий світ і ініціювала цифрову трансформацію у всіх сферах діяльності. За кілька місяців пандемія сформувала нову альтернативну віртуальну реальність, поширення якої не припиниться навіть після карантину [7]. Штучний інтелект і безконтактні технології отримали новий поштовх для розвитку, і після кризи людство вступить у нову цифрову еру. Посилена залежність від цифрових 
комунікацій триватиме після пандемії та впливатиме на дизайн та функціонування урбанізованих середовищ. У тренді підвищення екобезпеки побудованого середовища із застосуванням інноваційних принципів зеленого будівництва та пошук альтернативних варіантів цифрової трансформації для створення більш стійкого та безпечного простору.

Дизайн приміщень. Для запобігання поширенню COVID-19 важливо розуміти потенційну динаміку передачі інфекції. ВОО3 рекомендує дотримуватись відстані 1,5-2 м між особами для мінімізації ризику зараження, проте нещодавні дослідження підтверджують гіпотезу про передачу вірусу на відстань понад 2 м від зараженої людини [28]. Дослідники університету штату Оклахома змоделювали різні умови навколишнього середовища та руху повітря і з'ясували, що соціальної дистанції 2 м достатньо, тільки якщо атмосферне повітря є статичним [25]. Вірусні частинки можуть передаватися як повітряно-крапельним шляхом, так і через прямі та опосередковані контакти. Віріони можуть безпосередньо осідати на поверхнях або переноситись повітряними потоками, тому важливо визначити джерела турбулентності в приміщенні [15]. Інженери продовжують працювати у напрямку пошуку рішень для знезараження та захисту. Вже розроблено різноманітні варіанти пристроїв, які знижують ризики зараження: пристрої для відкриття дверей ногою, захисний екран для обличчя, пристрій для дезінфекції гаджетів, санітайзери у вигляді браслетів та розпилювачів різної форми. Компактний ультрафіолетовий рециркулятор можна легко зробити 3 недорогих комплектуючих і деталей, надрукованих на 3D-принтері. Таким пристроєм освітні установи можуть забезпечувати себе без значних фінансових витрат [9].

Багатоповерхові будівлі внаслідок високої щільності людей стали зонами підвищеного ризику під час пандемії, особливо це стосується спільних зон, ліфтів та вузьких проходів, де неможливо дотримуватись безпечної відстані $[12,28]$. Людям потрібні будинки, які можуть забезпечити соціальну ізоляцію та ефективний захист від інфекцій, що повинно знайти відображення у майбутніх стратегіях проектування будівель. Дослідження поширення інфекцій повітряно-крапельним шляхом у приміщеннях показало, що 80\% інфекційних захворювань передаються при дотику до забруднених поверхонь [28]. Джерелом інфекції може стати будь-яка поверхня, якої торкаються люди. У майбутніх проектах необхідно передбачити можливість безконтактного виклику ліфтів та автоматичного відкриття дверей, ширші коридори та дверні отвори, додаткові сходи та збільшення кількості перегородок, які дозволять уникати контактів 3 іншими мешканцями [22]. Тому в умовах пандемії особливої актуальності набувають безконтактні технології, наприклад програми управління ліфтами, дверми та усіма вимикачами за допомогою спеціального додатку у смартфоні [25].

У постпандемічний період високий пріоритет буде надаватися самодостатнім будівлям та відокремленому способу життя [6]. У нагоді стануть стратегії зеленого будівництва щодо енергоефективних систем опалення та вентиляції, підвищення якості внутрішнього середовища будівель. Розробляються індивідуальні проекти щодо альтернативних способів водопостачання та виробництва продуктів харчування. Будинки перестануть бути статичними об'єктами і стануть динамічними модульними системами, які можна буде змінювати у відповідності до нових потреб. 
В умовах карантину люди ще більше часу проводять у штучному побудованому середовищі, тому саме зараз слід згадати про високі критерії якості параметрів внутрішніх приміщень, які застосовуються у зеленому будівництві. Стратегії, спрямовані на збереження здоров'я людей, які тривалий час перебувають у приміщеннях, включають збільшення природного освітлення, поліпшення вентиляції, усунення токсичних речовин у повітрі, використання природних матеріалів, оздоровче озеленення приміщень [22]. У зв'язку з цим життєво важливо проектувати будівлі з великими вікнами, терасами на даху, балконами та внутрішніми двориками [16]. Віртуальні експерименти на основі моделювання повітряних потоків дозволяють визначити небезпечні зони і виявити інші фактори, які можуть призвести до поширення вірусу. Суттєве підвищення екобезпеки досягається шляхом корекції системи вентиляції, зміни режиму провітрювання приміщення, установки перегородок та захисних екранів та ін. Навіть проста перестановка меблів може значно знизити ризик передачі інфекції і при цьому не потребує значних фінансових витрат. Дизайнери інтер'єрів надаватимуть перевагу гігієнічним та антибактеріальним матеріалам, які легко піддаються санітарній обробці [23]. Сучасні технології пропонують різноманітні стратегії автоматичного очищення з використанням вбудованих в інтер'єри приладів для санітарного обприскування, дезінфікуючого освітлення та температурної обробки приміщень [24].

Домашній офic. Режим дистанційної роботи як альтернативний механізм праці було розроблено ще у 1970-х роках. Під час карантину навіть компанії, які категорично не підтримували концепцію віддаленої роботи, були змушені дозволити співробітникам працювати вдома. Практично всі відмічали позитивний момент від того, що не доводиться витрачати час на дорогу до роботи [22]. Але робота з дому виявилась справжнім викликом для тих, у кого не було можливостей відокремитись від інших членів родини. Крім того, не всім вдалося ефективно зорганізуватись у досягненні балансу між роботою та приватним життям, що негативно відобразилось на результатах праці і практично всі потерпали від соціальної ізоляції [26]. 3 огляду на те, що навіть після закінчення карантину більше людей працюватиме вдома, в сучасному інтер'єрному плануванні необхідно приділити більше уваги облаштуванню робочого місця вдома. Новий формат житла передбачає зміну просторової організації для відокремлення роботи від дозвілля, дітей від дорослих, оперуючи у більшості випадків обмеженою площею. В стандартах зеленого будівництва чітко прописані критерії організації домашнього офісу, зокрема відзначається необхідність звукоізоляції, контроль відблисків і освітлення, технічне обладнання, ергономічні меблі [7]. Девелопери повинні замислитись, якими будуть будинки, щоб було зручно жити і працювати в компактному просторі. Перші поверхи житлових центрів доцільно переобладнати в коворкінги, куди можна буде спуститися з власної квартири, попрацювати в спокійній атмосфері і повернутися додому у будь-яку мить. При оцінці будівельних проектів згідно з критеріями зеленого будівництва за домашній офіс нараховуються спеціальні бали, оскільки це зменшує транспортні викиди та підвищує показники працездатності при раціональній організації робочого місця та ефективному плануванні.

Нова офісна концеепія. Великі компанії вже відмовляються від оренди великих офісів, розраховуючи на те, що частина людей буде працювати вдома. 
Однак постійно працювати вдома підходить не всім працівникам і такий режим не може забезпечити повноцінного функціонування багатьох компаній, тому після карантину частина людей повернеться в офіси. Але пандемія триває, і вже прогнозують поширення нових інфекційних захворювань, тому доведеться кардинально змінити загальну концепцію офісних приміщень [24]. Тенденція відкритого спільного офісного простору вже втратила свою актуальність [7]. Необхідність дотримання соціальної дистанції обумовлює перехід від структурованого офісного середовища до більш гнучких конструкцій з мобільними перегородками. Компанії планують застосовувати ультрафіолетове бактерицидне опромінення для глибокої дезінфекції офісів вночі та кімнат для переговорів під час перерв [19]. У пошуках кращих варіантів природної вентиляції та здорового дизайну звертаються до технологій зеленого будівництва. Фахівці з нерухомості активно обговорюють зміни у структурі попиту на офіси і шляхи адаптації офісних приміщень до нових вимог.

Тимчасове переобладнання лікарень. Пандемія COVID-19 представляє безпрецедентний виклик для систем охорони здоров'я на міжнародному рівні. Медичні заклади перевантажені, більшість країн за кілька тижнів побудували польові та тимчасові лікарні або повторно використали інші типи будівель та приміщення, щоб додати тисячі ліжок. Основні стратегії, що використовуються в системах охорони здоров'я під час пандемії, включають модульні конструкції або трансформацію підходящих приміщень у тимчасові лікарні [7]. У лікарні Vic (Мельбурн, Австралія) на автостоянці побудували тимчасове відділення реанімації, що складається зі збірних двоповерхових контейнерів. Модульну конструкцію було споруджено на стоянці лікарні Лейшеншань (Ухань, Китай). Тут розмістилося 1600 ліжок у збірних модулях в сталевих каркасах над бетонними фундаментами. Італійський архітектор i професор спроектував капсули для інтенсивної терапії в транспортному контейнері під назвою CURA. Відсіки з'єднані надувними коридорами та оснащені біологічними системами (CURA, Мілан, Італія). Конференц-центр Javits у Нью-Йорку перетворено у тимчасову польову лікарню на 2910 ліжок для пацієнтів з COVID-19. Виставочний центр Excel Nightingale (Лондон, Великобританія) перетворився у лікарню на 500 місць, обладнану вентиляторами та потужною системою нагнітання кисню. Надувна лікарня швидкої допомоги у місті Пачука (Мексика) площею 1000 квадратних метрів підготовлена для щоденного огляду до 80 пацієнтів з COVID-19. В медичному центрі UCSF (затока Сан-Франциско, США) встановлено два відкритих намети, що функціонують як приміщення для сортування та невідкладної допомоги, місця очікування та лікування для прогнозованого напливу пацієнтів з COVID-19 [28].

Модульна будівельна стратегія, що стає все популярнішою в умовах пандемії COVID-19, зарекомендувала себе як ефективний захід у кризових ситуаціях [26]. Це важливо для задоволення різноманітних вимог медичних служб із готовими стандартизованими компонентами, завдяки яким будівлі розширюють функціональні можливості та простір для лікування та карантину [18]. Адаптивне повторне використання також $є$ ефективним та динамічним підходом до створення аварійних об'єктів. Під час пандемії спортивні споруди, стоянки та інші будівлі перетворюються на медичні установи та тимчасові лікарні. Розробляються вимоги для більш ефективних, результативних та 
гнучких планів багатофункціонального просторового використання у разі виникнення нових криз [16]. Ця стратегія вигідна в поєднанні 3 іншими передовими технологіями у будівельному секторі, особливо 3 концепцією зеленого будівництва.

\section{Обговорення результатів}

За минулими прогнозами ООН, до 2050 року 70\% населення світу повинно жити в містах, однак тепер закрадається сумнів щодо подібного сценарію розвитку подій. Внаслідок пандемії більш ймовірним здається сповільнення урбанізації і початок поступової деурбанізації, що відкриває нові перспективи для розвитку сільських територій та маленьких міст. Епоха затяжного карантину з особливими вимогами до гігієни, соціальної дистанції, здорового способу життя ставить під питання сам факт існування мегаполісів у їх сучасному вигляді. Цей процес сприятиме покращенню стану навколишнього середовища i екобезпеки, розвитку зеленого будівництва і оздоровленню людства. $€$ шанси, що побудоване середовище зміниться на краще, як це вже відбувалось в історії людства, коли після пандемій розвивались нові архітектурні стилі.

Парадоксально, але завдяки пандемії нові тенденції планування міського середовища зосередились на аспектах здоров'я населення - від стимулювання фізичної активності до забезпечення психологічної та ментальної рівноваги. Згідно з прогнозами постпандемічна архітектура буде розвиватись у напрямку врівноваження психосоціальних проблем та підвищення рівня екобезпеки мегаполісів. Особливої актуальності набувають завдання адаптації соціально значимих об'єктів до роботи в умовах після пандемії коронавірусної інфекції 3 використанням імітаційного моделювання. Такі моделі дозволяють перевірити різні сценарії функціонування місць масового скупчення людей з урахуванням переміщення потоків. Результати імітаційного моделювання можна використовувати для організації простору оптимальним чином 3 метою зниження щільності потоку людей 3 одночасним збільшенням пропускної спроможності.

Життя після пандемії COVID-19 ніколи не вже не буде як раніше. Багато заходів, прийнятих під час надзвичайної ситуації, вже стали частиною повсякденного життя, змінили звички та поведінку людей. Під цим впливом будуть змінюватися підходи до архітектури та містобудування, причому як у негативному, так і у позитивному сенсі. Поки що урбаністичне середовище не пристосовано до вимог екобезпеки в умовах пандемії, але люди швидко вчаться, бо тільки такий підхід забезпечує виживання. Пандемія не триватиме вічно, але під iї впливом зміниться не тільки стиль взаємодії людей, а й побудоване середовище [17]. Нові підходи до планування міської інфраструктури та дизайну приміщень підвищать екобезпеку урбаністичних територій і знизять щільність населення у мегаполісах.

Нова парадигма урбосередовища, захищеного від пандемій, вдосконалює існуючі стратегії проектування на всіх рівнях - від дизайну інтер'єру до планування міста. Однак вибір найкращої антивірусної стратегії залежить від багатьох факторів і передбачає довгострокові реформи. Оптимальним базисом для створення екобезпечного міського середовища нового типу стануть стандарти зеленого будівництва. Багато питань все ще вимагають подальших 
мультидисциплінарних досліджень у пошуку шляхів подолання сьогоденних і майбутніх пандемічних атак та надзвичайних ситуацій на всіх рівнях безпеки.

Від будівельної галузі очікують формування нових стандартів і правил, що відповідають вимогам екобезпеки в епоху пандемічних загроз. Конкурентну перевагу отримають ті компанії, які змогли своєчасно адаптуватись i запропонували інноваційні проекти у відповідності до нових цінностей i потреб. Пандемія COVID-19 переконливо продемонструвала необхідність перегляду стратегій проектування та теорій планування урбаністичних територій та будівель. Уроки, отримані під час пандемії, переконують в необхідності створення здорового та стійкого побудованого середовища на підгрунті стандартів зеленого будівництва.

\section{Висновки}

1. Пандемії минулого лежать в основі трансформацій урбаністичного середовища і протягом всієї історії людства впливали на архітектуру, дизайн та інфраструктуру міст, які сформувалися під тиском запобіжних заходів, розроблених для забезпечення здоров'я, гігієни та комфорту населення.

2. Тенденції будівництва завжди відображали здатність еволюціонувати після кризи, а в умовах пандемії COVID-19 найбільш вразливими до ризику зараження виявились густонаселені мегаполіси, тому для протидії епідеміям та іншим можливим надзвичайним ситуаціям необхідно створити нові стратегії міського простору і екобезпечного середовища.

3. Моделювання надзвичайних ситуацій за допомогою цифрових технологій дозволяє створити оперативну систему реагування і прогнозування різних сценаріїв розвитку екологічно небезпечних ситуацій. Необхідно підвищувати просторову функціональність та децентралізацію мегаполісів із збільшенням потенціалу мікромобільності і новими транспортними стратегіями.

4. Актуальними стають високі критерії якості параметрів побудованого середовища, які застосовуються у зеленому будівництві, що спрямовано на збереження здоров'я людей на всіх етапах життєвого циклу будівель та оточуючої інфраструктури, тому стандарти зеленого будівництва рекомендовано у якості фундаментального підгрунтя процесу трансформації урбанізованого середовища для підвищення рівня екобезпеки.

5. Сучасні технології передбачають різноманітні методи автоматичного очищення з використанням вбудованих в інтер'єри приладів для санітарного обприскування, дезінфікуючого освітлення та температурної обробки приміщень, безконтактні технології управління будівлями. Рекомендації включають збільшення природного освітлення, поліпшення вентиляції, усунення небезпечних чинників 3 повітря та поверхонь, використання природних матеріалів, оздоровче озеленення приміщень.

6. Від будівельної галузі очікують формування нових стандартів і правил, що відповідають вимогам екобезпеки в епоху пандемічних загроз, при цьому конкурентна перевага закріпиться за тими компаніями, які змогли своєчасно адаптуватись і запропонували інноваційні проекти у відповідності до нових цінностей і потреб. 


\section{СПИСОК ЛІТЕРАТУРИ}

1. Горбулін В. П., Даник Ю. Г. Національна безпека України: фокус пріоритетів в умовах пандемії // Вісник НАН України. - 2020. - № 5. - С. 3-18.

2. Кривомаз Т. Актуальна ли опасность коронавирусной атипичной пневмонии? // Фармацевт практик - 2017. - № 1. - С. 18-20.

3. Кривомаз Т.І., Карпенко Н.С. Зелені стандарти для покращення офісної діяльності в нових умовах // Екологічна безпека та природокористування. - 2020. - 34(2). C. 5-21.

4. Шах С. Пандемия: Всемирная история смертельных инфекций. - 2017. - Альпина нон-фикшн. -358 с.

5. Abd-Elhafeez M., ELmokadem A., Megahed N., El-Gheznawy D. Methodology for the design and evaluation of green roofs in Egypt // Port-Said Engineering Research Journal. 2016. - 20(1). - P. 35-43.

6. Ali M., Dom M., Sahrum M. Self-sufficient community through the concepts of collective living and universal housing // Procedia - Social and Behavioral Sciences. - 2012. - 68. P. 615-627.

7. Allam Z., Jones D. Pandemic stricken cities on lockdown. Where are our planning and design professionals (now, then and into the future) // Land Use Policy. - 2020. - 97. 1048052 [PMC free article].

8. Andersen K.G., Rambaut A., Lipkin W.I., Holmes E.C., Garry R.F. The proximal origin of SARS-CoV-2. // Nature Medicine. - 2020. - 26 - P. 450-452.

9. Belzunegui-Eraso A., Erro-Garcés A. Teleworking in the context of the Covid-19 crisis // Sustainability. - 2020. - 12(9). - P. 36-62.

10. Bourouiba L. Turbulent gas clouds and respiratory pathogen emissions: Potential implications for reducing transmission of COVID-19 // JAMA. - 2020. - 323(18). - P. 18371838.

11. Campisi T., Acampa G., Marino G., Tesoriere G. Cycling master plans in Italy: The I-BIM feasibility tool for cost and safety assessments //Sustainability. - 2020. - 12(11). P. 23-47.

12. Capolongo S., Rebecchi A., Buffoli M., Letizia A., Carlo S. COVID-19 and cities: From urban health strategies to the pandemic challenge. A decalogue of public health opportunities // Acta Biomedica. - 2020. - 91(2). - P. 13-22.

13. CDC. Centers for Disease Control and Prevention; 2020. COVID-19 guidance for shared or congregate housing. [Електронний pecypc]. - Режим доступу : https://www.cdc.gov/coronavirus/2019-ncov/community/shared-congregate-house/guidanceshared-congregate-housing.html. - Назва з екрана. - Дата перегляду: 19.11.2020.

14. Chick R., Clifton G., Peace K., Propper B., Hale D., Alseidi A., Vreeland T. Using technology to maintain the education of residents during the COVID-pandemic // Journal of Surgical Education. - 2020. - 77(4). - P. 729-732.

15. Cirrincione L., Plescia F., Ledda C., Rapisarda V., Martorana D., Moldovan R.E., Cannizzaro E. COVID-19 pandemic: Prevention and protection measures to be adopted at the workplace // Sustainability. - 2020. - 12(9). - P. 3-36.

16. Goniewicz K., Khorram-Manesh A., Hertelendy A., Goniewicz M., Naylor K., Burkle F. Current response and management decisions of the European union to the COVID-19 outbreak: A review // Sustainability. - 2020. - 12(9). - P. 18-38.

17. Hakovirta M., Denuwara N. How COVID-19 redefines the concept of sustainability // Sustainability. - 2020. - 12(9). - P. 27-37.

18. Hishan S., Ramakrishnan S., Qureshi M., Khan N., Al-Kumaim N. Pandemic thoughts, civil infrastructure and sustainable development: Five insights from COVID-19 across travel lenses // Talent Development \& Excellence. - 2020. - 12. - P. 1690-1696.

19. Horve P., Lloyd S., Mhuireach G., Dietz L., Fretz M., MacCrone G., Ishaq S. Building upon current knowledge and techniques of indoor microbiology to construct the next era of 
theory into microorganisms, health, and the built environment // Journal of Exposure Science \& Environmental Epidemiology. - 2020. - 30. - P. 219-235.

20. Kryvomaz T., Varavin D. Applying of green building standards for implementation of the city development strategies in Kyiv // Useful, 2019 [Електронний ресурс]. - Режим доступу : https://useful.academy/3-1-2019-0003-varavin. - Назва 3 екрана. - Дата перегляду: 19.11.2020.

21. Megahed N. Photocatalytic technology in architectural context: From science to societal debates // Indoor and Built Environment. - 2013. - 23(4). - P. 603-614.

22. Megahed N.A., Ehab M.G. Antivirus-built environment: Lessons learned from Covid-19 pandemic // Sustainable Cities and Society. - 2020. - 61. - P. 102-350.

23. Musselwhite C., Avineri E., Susilo Y. Editorial JTH 16 - the Coronavirus Disease COVID-19 and implications for transport and health // Journal of Transport \& Health. - 2020. 16 [PMC free article].

24. Nicola M., Alsafi Z., Sohrabi C., Kerwan A., Al-Jabir A., Iosifidis C., Agha R. The socioeconomic implications of the coronavirus and COVID-19 pandemic: A review // International Journal of Surgery. - 2020. - 78. - P. 185-193.

25. OSU researchers examine social distancing models, encourage caution // Oklahoma State University, 2020 [Електронний pecypc]. - Режим доступу : https://news.okstate.edu/articles/communications/2020/osu-researchers-examine-social-

distancing-models-encourage-caution.html. - Назва 3 екрана. - Дата перегляду: 19.11.2020.

26. Scarfone R., Coffin S., Fieldston E., Falkowski G., Cooney M., Grenfell S. Hospitalbased pandemic influenza preparedness and response: Strategies to increase surge capacity // Pediatric Emergency Care. - 2011. - 27(6). - P. 565-572.

27. World Green Building Council (WGBC) [Електронний ресурс]. - Режим доступу : http://www.worldgbc.org/what-green-building. - Назва 3 екрана. - Дата перегляду: 19.11.2020.

28. World Health Organization (WHO) [Електронний ресурс]. - Режим доступу : https://www.who.int. - Назва з екрана. - Дата перегляду: 19.11.2020.

Стаття надійшла до редакиії 03.07.2020 і прийнята до друку після рецензування 23.10.2020

\section{REFERENCES}

1. Horbulin, V.P., \& Danyk, Yu.H. (2020). Natsionalna bezpeka Ukrainy: fokus priorytetiv $\mathrm{v}$ umovakh pandemii [National security of Ukraine: focus of priorities in a pandemic]. Visnyk NAN Ukrainy, 5, 3-18. (in Ukrainian)

2. Kryvomaz, T.I. (2017). Aktual'na li opasnost' koronavirusnoj atipichnoj pnevmonii? [Is the danger of coronavirus atypical pneumonia relevant?]. Farmacevt praktik, 1, 18-20. (in Russian)

3. Kryvomaz, T., \& Karpenko, N. (2020). Green standards for improving office activities in new conditions. Environmental Safety And Natural Resources, 34(2), 5-21. doi:http://dx.doi.org/10.32347/2411-4049.2020.2.5-21 (in Ukrainian)

4. Shah, S. (2017). Pandemija: Vsemirnaja istorija smertel'nyh infekcij [Pandemic: A Worldwide History of Fatal Infections]. Al'pina non-fikshn. (in Russian)

5. Abd-Elhafeez, M., ELmokadem, A., Megahed, N., \& El-Gheznawy, D. (2016). Methodology for the design and evaluation of green roofs in Egypt. Port-Said Engineering Research Journal, 20(1), 35-43.

6. Ali, M., Dom, M., \& Sahrum, M. (2012). Self-sufficient community through the concepts of collective living and universal housing. Procedia - Social and Behavioral Sciences, 68, 615-627. 
7. Allam, Z., \& Jones, D. (2020). Pandemic stricken cities on lockdown. Where are our planning and design professionals (now, then and into the future). Land Use Policy, 97, 1048052 [PMC free article].

8. Andersen, K.G., Rambaut, A., Lipkin, W.I., Holmes, E.C., \& Garry, R.F. (2020). The proximal origin of SARS-CoV-2. Nature Medicine, 26, 450-452.

9. Belzunegui-Eraso, A., \& Erro-Garcés, A. (2020). Teleworking in the context of the Covid-19 crisis. Sustainability, 12(9), 36-62.

10. Bourouiba, L. (2020). Turbulent gas clouds and respiratory pathogen emissions: Potential implications for reducing transmission of COVID-19. JAMA, 323(18), 1837-1838.

11. Campisi, T., Acampa, G., Marino, G., \& Tesoriere, G. (2020). Cycling master plans in Italy: The I-BIM feasibility tool for cost and safety assessments. Sustainability, 12(11), 23-47.

12. Capolongo, S., Rebecchi, A., Buffoli, M., Letizia, A., \& Carlo, S. (2020). COVID-19 and cities: From urban health strategies to the pandemic challenge. A decalogue of public health opportunities. Acta Biomedica, 91(2), 13-22.

13. COVID-19 guidance for shared or congregate housing. CDC. Centers for Disease Control and Prevention. (2020). Retrieved 19.11.2020 from: https://www.cdc.gov/coronavirus/2019ncov/community/shared-congregate-house/guidance-shared-congregate-housing.html.

14. Chick, R., Clifton, G., Peace, K., Propper, B., Hale, D., Alseidi, A., \& Vreeland, T. (2020). Using technology to maintain the education of residents during the COVIDpandemic. Journal of Surgical Education, 77(4), 729-732.

15. Cirrincione, L., Plescia, F., Ledda, C., Rapisarda, V., Martorana, D., Moldovan, R.E., \& Cannizzaro, E. (2020). COVID-19 pandemic: Prevention and protection measures to be adopted at the workplace. Sustainability, 12(9), 3-36.

16. Goniewicz, K., Khorram-Manesh, A., Hertelendy, A., Goniewicz, M., Naylor, K., \& Burkle, F. (2020). Current response and management decisions of the European union to the COVID-19 outbreak: A review. Sustainability, 12(9), 18-38.

17. Hakovirta, M., \& Denuwara, N. (2020). How COVID-19 redefines the concept of sustainability. Sustainability, 12(9), 27-37.

18. Hishan, S., Ramakrishnan, S., Qureshi, M., Khan, N., \& Al-Kumaim, N. (2020). Pandemic thoughts, civil infrastructure and sustainable development: Five insights from COVID-19 across travel lenses. Talent Development \& Excellence, 12, 1690-1696.

19. Horve, P., Lloyd, S., Mhuireach, G., Dietz, L., Fretz, M., MacCrone, G., \& Ishaq, S. (2020). Building upon current knowledge and techniques of indoor microbiology to construct the next era of theory into microorganisms, health, and the built environment. Journal of Exposure Science \& Environmental Epidemiology, 30, 219-235.

20. Kryvomaz, T., \& Varavin, D. (2019). Applying of green building standards for implementation of the city development strategies in Kyiv. Useful. Retrieved 19.11.2020 from: https://useful.academy/3-1-2019-0003-varavin.

21. Megahed, N. (2013). Photocatalytic technology in architectural context: From science to societal debates. Indoor and Built Environment, 23(4), 603-614.

22. Megahed, N.A., \& Ehab, M.G. (2020). Antivirus-built environment: Lessons learned from Covid-19 pandemic. Sustainable Cities and Society, 61, 102-350.

23. Musselwhite, C., Avineri, E., \& Susilo, Y. (2020). Editorial JTH 16 - the Coronavirus Disease COVID-19 and implications for transport and health. Journal of Transport \& Health, 16 [PMC free article].

24. Nicola, M., Alsafi, Z., Sohrabi, C., Kerwan, A., Al-Jabir, A., Iosifidis, C., \& Agha, R. (2020). The socio-economic implications of the coronavirus and COVID-19 pandemic: A review. International Journal of Surgery, 78, 185-193.

25. OSU researchers examine social distancing models, encourage caution. (2020). Oklahoma State University. Retrieved 19.11.2020 from: https://news.okstate.edu/articles/communications/2020/osu-researchers-examine-socialdistancing-models-encourage-caution.html. 
26. Scarfone, R., Coffin, S., Fieldston, E., Falkowski, G., Cooney, M., \& Grenfell, S. (2011). Hospital-based pandemic influenza preparedness and response: Strategies to increase surge capacity. Pediatric Emergency Care, 27(6), 565-572.

27. World Green Building Council (WGBC). Retrieved 19.11.2020 from: http://www.worldgbc.org/what-green-building.

28. World Health Organization (WHO). Retrieved 19.11.2020 from: https://www.who.int.

The article was received 03.07.2020 and was accepted after revision 23.10.2020

\section{Кривомаз Тетяна Іванівна}

доктор технічних наук, кандидат біологічних наук, професор кафедри охорони праці та навколишнього середовища Київського національного університету будівництва та архітектури

Адреса робоча: 03037 Україна, м. Київ, проспект Повітрофлотський, 31

ORCID ID: 0000-0002-4161-9702 e-mail: ecol@i.ua

\section{Варавін Дмитро Володимирович}

аспірант Київського національного університету будівництва та архітектури

Адреса робоча: 03037 Україна, м. Київ, проспект Повітрофлотський, 31

ORCID ID: 0000-0002-4161-9702 e-mail: d.varavin@icloud.com 